$14^{\text {th }}$ Conf. Agric. Develop. Res., Fac. of Agric., Ain Shams Univ., March, 2019, Cairo, Egypt

Special Issue, 27(1), 1053 - 1073, 2019

1073

Website: http://strategy-plan.asu.edu.eg/AUJASCI/

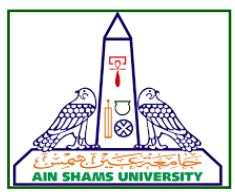

\title{
ANALYSIS OF EGYPTIAN AGRICULTURAL FOREIGN TRADE WITH THE COUNTRIES OF THE EURO - ASIAN UNION
}

\author{
Omairi, A.A., Salem M.H., Abdelmaqsoud, A.M., Salwa M. Abd ELMonem \\ Agric. Economics Dept., Fac. of Agric., Ain Shams Univ., P.O. Box 68, Hadayek Shobra 11241, \\ Cairo, Egypt
}

${ }^{*}$ Corresponding author: $\underline{\mathrm{dr}}$.hamdy.salem@gmail.com

Received 25 September, 2018,

Accepted 14 October, 2018

\begin{abstract}
The study aims at identifying the analysis of the Egyptian agricultural foreign trade with the countries of the Euro-Asian Union. The study problem , its objectives and the research method Where identified in the study. Where, there is a lack of information on the expected results or the role that the proposed free trade agreement between Egypt and the Euro-Asian Union could play and the requirements for maximizing the positive results and minimizing the negative consequences if this agreement is signed. Therefore, the research aims to identify the positive and negative results on the Egyptian economy under the proposed agreement, which contributes to reducing the negatives and supporting the positive factors to achieve effective decision-making. The study included four chapters. First, identifying the stages of economic integration. The second chapter was studying the economic interrelationships between the Russian Federation, Egypt, Belarus, Armenia and Kazakhstan, and the third chapter was the identification of commodity trade relations between Egypt and Eurasian countries during the period 2001-2017 through exports and imports between Egypt and
\end{abstract}

the countries of the Euro-Asian Union The most important trading partner of Egypt among these countries is the Russian Federation, where the value of trade exchange between the two countries in 2017 to more than 4 billion dollars, including 3.6 billion imports to Egypt and 0.5 billion exports from Egypt to Russia, The fourth chapter was the use of trade indicators to reveal trade opportunities with the countries of the Euro-Asian Customs Union. Three indicators were used: 1- Conditions of trade, 2- Agricultural trade compatibility, 3- Price competitiveness, The tendency of the terms of exchange for Egypt in many commodities of vegetables and fruits in the studied markets and the most important Russian market and it shows the agricultural trade compatibility of these commodities and the advantage of some Egyptian commodities such as oranges, potatoes and grapes have a significant competitive advantage in the Russian market with great importance. The research included several recommendations, including the promotion of intraagricultural trade between Egypt and the EuroAsian countries through preferential agreements, especially with Russia, Armenia and Kazakhstan.

Keywords: WTO, (EAEU), Regional Economic Integration, Terms of trade, Agricultural trade compatibility, Price competitiveness 